\title{
RESIDENTIAL HEATING AND COOLING LOADS AND COSTS FOR THE SOUTH
}

\author{
Andrew S. Lau \\ Ted D. Hyatt
}

January 1982

prepared for

U.S. DEPARTMENT OF ENERGY

under contract number DE-ACO2-79CS30166

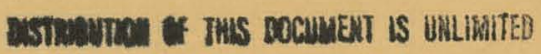




\section{DISCLAIMER}

This report was prepared as an account of work sponsored by an agency of the United States Government. Neither the United States Government nor any agency Thereof, nor any of their employees, makes any warranty, express or implied, or assumes any legal liability or responsibility for the accuracy, completeness, or usefulness of any information, apparatus, product, or process disclosed, or represents that its use would not infringe privately owned rights. Reference herein to any specific commercial product, process, or service by trade name, trademark, manufacturer, or otherwise does not necessarily constitute or imply its endorsement, recommendation, or favoring by the United States Government or any agency thereof. The views and opinions of authors expressed herein do not necessarily state or reflect those of the United States Government or any agency thereof. 


\section{DISCLAIMER}

Portions of this document may be illegible in electronic image products. Images are produced from the best available original document. 


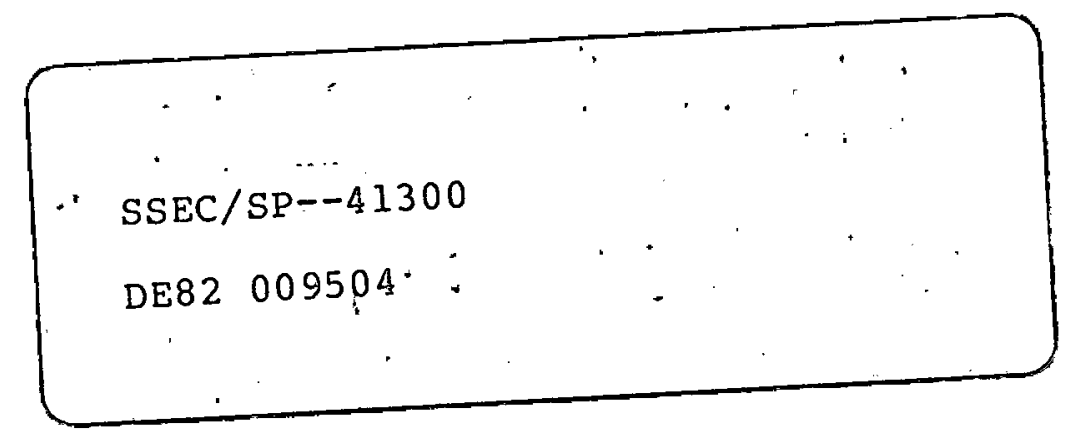

DISCLAIMER

This report was prepared as an account of work sponsored by the Southern Solar Energy Center, a contractor of the United States Government. Neither the Southern Solar Energy Center, the United States Government, nor any agency thereof, nor any of their employees, makes any warranty, express or implied, or assumes any legal liability or responsibility for the accuracy, completeness, or usefulness of any information, apparatus, product, or process disclosed, or represents that its use would not infringe privately owned rights. References herein to any specific compercial product, process, or service by trade name, trademark, manufacturer, or otherwise, does not necessarily constitute or imply its endorsement, recommendation, or favoring by the Southern Solar Energy Center, the United States Government, or any agency thereaf. The views and opinions of authors expressed herein do not necessarily state or reflect those of the Southern Solar Energy Center, the United States Government, nor any agency thereof. 
RESIDENTIAL HEATING AND COOLING LOADS

AND COSTS FOR THE SOUTH

\author{
Andrew S. Lau \\ Ted D. Hyatt \\ Southern Solar Energy Center \\ 61 Perimeter Park \\ Atlanta, GA 30341
}

January 1982 


\section{ABSTRACT}

This report examines typical residential heating and cooling loads for 24 southern cities and six other U.S. cities. A 1536-square-foot house is examined, with concrete slab floor, frame construction, ventilated attic, and glazing area equivalent to 12 percent of the floor area. Five basic variations of this house were analyzed: two insulation levels with two compass orientations each, and a sun-tempered case. The building load calculations were based on a non-rigorous methodology typically used within the building community today. The estimated heating and cooling loads and the impact of insulation, orientation, and sun-tempering are illustrated with regional maps. Typical fuel costs and heating systems are also examined and shown to have a major role in determining whether the building design emphasis should be on heating or cooling. 


\section{ACKNOWLEDGEMENT}

Funding for this effort was provided by the U.S. Department of Energy under contract no. DE-AC02-79CS30166. The authors gratefully acknowledge the support of Don Abrams for the concept and initial effort and Celeste Porter, Greg Winkler, and Dianne Stone for graphic work. 


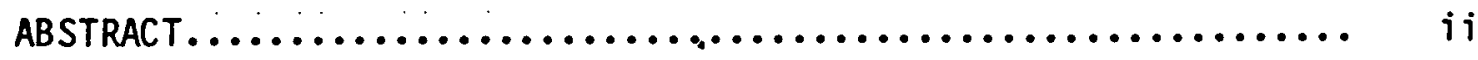

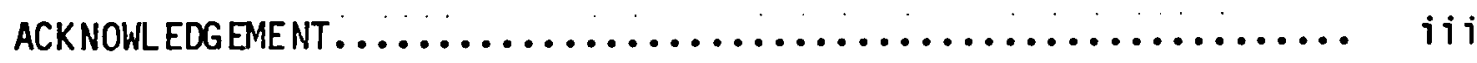

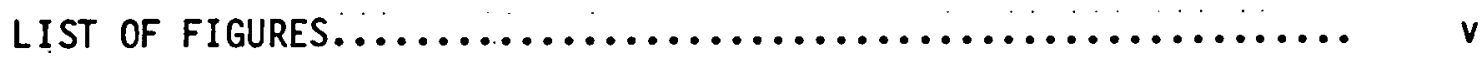

LIST OF TABLES $\ldots \ldots \ldots \ldots \ldots \ldots \ldots \ldots \ldots \ldots \ldots \ldots \ldots \ldots \ldots \ldots \ldots \ldots \ldots \ldots \ldots$

1.0 INTRODUCTION.....................................

2.0 BUILDING DESCRIPTION..............................

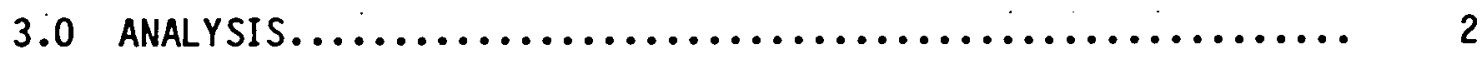

3.1 Heating Loads................................. 2

3.2 Cooling Loads.................................. 3

3.3 Fuel Costs and Efficiencies..................... 4

4.0 RESULTS....................................... 5

4.1 Heating and Cooling Load Balance................... 5

4.2 Effect of Increased Insulation, House Orientation, and Sun Tempering............................. 6

4.3 Heating and Cooling Cost Ratios.................. 7

5.0 SUMMARY....................................... 8

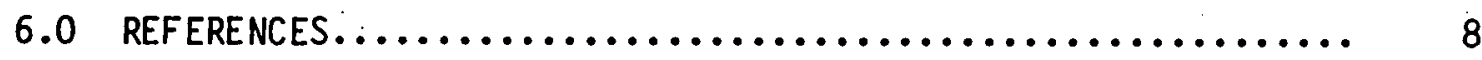


Figure Number

Title

Page

Building Descriptions. 13

2

Standard House Loads and Heating to

Cooling Load Ratios for East-West Axis......... 14

Standard House Loads and Heating to Cooling Load Ratios for North-South Axis............. 15

Energy-Conserving House Loads and Heating to Cooling Load Ratios for East-West Axis.......... 16

Energy-Conserving House Loads and Heating to Cooling Load Ratios for North-South Axis....... 17

Sun-Tempered House Loads and Heating to Cooling Load Ratios................................ 18

Annual Energy Savings of Energy-Conserving House Over Standard House..............................

Annual Energy Savings From Changing EnergyConserving House Orientation to Face South..... 20

Annual Energy Savings From Relocating DoubleGlazing to South Side........................ 


\section{LIST OF TABLES}

Table Number

1

2

3
Title

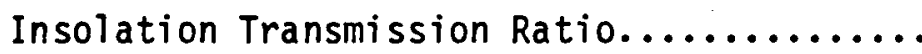

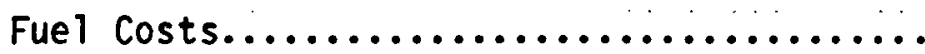

Annual Cost Ratio for Sun-Tempered Case.....
Page

10

11

12 


\subsection{INTRODUCTION}

Passive solar building techniques are gaining in popularity throughout the country. Most of the emphasis has been on lowering heating requirements, while cooling considerations have often been overlooked. This approach may be adequate for more northern, colder climates, but it is definitely not adequate for the South. As a first step at addressing the nature of heating and cooling in southern housing, this report assesses the typical residential loads for 24 southern cities and six other U.S. cities. Typical fuels, costs, and efficiencies are applied to the loads to indicate the estimated cost of heating and cooling.

\subsection{BUILDING DESCRIPTION}

The example building was chosen to be typical of the housing market in the South: a single-story, ranch-style house with gross dimensions of $32 \mathrm{ft} . \times 48$ ft. (1536 sq. ft.). The house is slab-on-grade, frame construction with a ventilated attic and dark roof. Five basic variations of this building were analyzed and are shown in Figure 1 .

Two house compass orientations were considered: an east-west axis and a north-south axis. The meaning of these orientations is shown in the upper part of Figure 1. Two insulation levels were considered for each house orientation; the "standard" house was chosen to represent the typical house built during the last several years. The "energy-conserving" house was chosen to represent a practical insulation level achievable with conventional construction techniques. Many southern builders are already using "energy-conserving" insulation levels in their new houses. These insulation levels, outlined in Figure 1, result in $U A$-values of $880 \mathrm{Btu} / \mathrm{hr}{ }^{\circ} \mathrm{F}$ for the "standard" house and $550 \mathrm{Btu} / \mathrm{hr}^{\mathrm{O}} \mathrm{F}$ for the "energy-conserving" house. The glazing area in all cases is equivalent to 12 percent of the floor area (184 sq. ft.) and is distributed as shown in Figure 1 . 
A fifth variation of the building is also considered: the sun-tempered house. The sun-tempered house has the energy-conserving insulation levels described above and an east-west axis. A code-minimum ( 8 percent of north half) amount of glazing was left on the north half of the sun-tempered house with the remaining glass shifted to the south side, for the same total percentage of glass - 12 percent. There is no east-west glazing in the sun-tempered case.

\subsection{ANALYSIS}

\subsection{Heating Loads}

The annual heating loads were calculated by the method outlined in the Passive Solar Design Handbook, Volume 2 (Reference 1), which accounts for solar gains through the windows. The Building Load Coefficients (BLCS) were calculated using American Society of Heating, Refrigerating, and Air Conditioning Engineers (ASHRAE) procedures (Reference 2). Correction factors to account for the non-reference amount of thermal mass were also included. Heating thermostats were set to $70^{\circ} \mathrm{F}$, with degree-days modified to account for the lower effective base temperature resulting from internal heat gains.

The Passive Solar Design Handbook does not adequately address direct-gain solar performance of single glazing; single glazing, however, is a viable option in parts of the South and is considered in this study. Therefore, to account for the single glazing in the standard house, the following two correction factors were used: First, the solar aperture was increased by the ratio of single glazing transmittance to double glazing transmittance, to account for the increased solar radiation available with single glazing. Then, the BLC was increased by the difference between the single glazing and double glazing thermal loss coefficients, with the difference multiplied by the true area of aperture. This latter correction is to account for the increased back-losses of single glazing. 
When accounting for the large areas of east-west facing glass during the heating season, the amount of light transmitted through the east-west windows was calculated and compared to the south-side transmitted radiation. Two methods were used to determine monthly average transmitted solar radiation. The average ratio of west-side solar radiation over south-side solar radiation for the heating season was calculated by weighting the monthly ratios with monthly degree-day values for October through April.

The results are reported in Table 1. Although these results are limited in scope, they indicate that a west- or east-facing window receives about half the useful solar radiation that a southern window receives during the heating season: Therefore, the east- and west-facing glass areas were multiplied by 0.50 and added to the solar collection area to determine the Solar Savings Fraction. Half of the east- and west-facing glass was also included in the Building Loss Coefficient.

For the two house orientations studied, this logic results in both orientations having equivalent aperture areas and building loss coefficients and, hence, auxiliary heating requirements. Of course, this does not mean that orientation is not important, because there will be a higher cooling load caused by insolation transmitted through the east- and west-facing glass. Also, it requires about twice as much east-west glass as south glass to achieve the same heating performance.

\subsection{Cooling Loads}

Cooling loads were calculated using ASHRAE's simplified residential sizing method (Reference 3 ) and equivalent full-load hours of operation as determined by National Association of Home Builders (NAHB) (Reference 4). The validity of this analysis method is not proven, but a study by sullivan, et. al. (Reference 5) found that incremental cooling loads predicted by this method show reasonable agreement with BLAST (Reference 6) computer predictions. Both the latent and sensible loads due to infiltration were included in the design cooling load. A psychrometric calculation was done for each city using an inside design condition of $75^{\circ} \mathrm{F}$ and 50 percent relative humidity. Two window treatments were considered: no shading and full shading by awnings. The cooling loads due to the two window treatments were averaged to calculate the heating-to-cooling load ratios. 


\subsection{Fuel Costs and Efficiencies}

Fuel costs were considered in order to examine the different loads from a consumer perspective. The fuel cost data, shown in Table 2, were obtained from the SOLCOST (Reference 7) data bank, where the fuel cost survey data was accumulated for summer 1980 and winter 1980-81. For cooling loads, the summer rates were used. For heating loads, the winter rates were used, where applicable. Fuel oil was not considered due to its limited use in most of the South.

In order to calculate annual energy costs, it was necessary to make assumptions about the seasonal operating efficiencies of the heating and cooling systems. To simplify the analysis, the efficiencies were assumed to be constant throughout the region. Following are the effective seasonal efficiencies used in the calculations (for heat pump, the effective efficiency is the seasonal performance factor times 100 percent):

$\begin{array}{rr}\text { Electric Resistance Heat } & 100 \% \\ \text { Heat Pump - Heating } & 200 \% \\ \text { Cooling } & 200 \% \\ \text { Natural Gas Heating } & 70 \%\end{array}$

These numbers are representative of the performance of current, typically used equipment operating in the mild southern climates. Actual seasonal efficiencies can differ from these assumptions around the region according to climate characteristics and equipment model.

The heating and cooling energy costs are determined in the following manner:

$$
\begin{aligned}
& \text { Heating Cost }=\left(Q_{h}\right)\left(C_{h f}\right) / E_{h} \\
& \text { Cooling Cost }=\left(Q_{c}\right)\left(C_{c f}\right) / E_{c}
\end{aligned}
$$


where:

$$
Q_{h}, Q_{c}=\quad \begin{aligned}
& \text { Annual building heating load and cooling load, respectively } \\
& \text { (MMBtu). }
\end{aligned}
$$

$c_{h f}, c_{c f}=$ Metered heating and cooling fuel costs, respectively (\$/MMBtu).

$E_{h}, E_{c}=$ Seasonal heating and cooling system efficiencies, in fractional form, respectively.

These relations can be used with the load data presented later to calculate costs for any HVAC system and fuel type.

\subsection{RESULTS}

\subsection{Heating and Cooling Load Balance}

The calculated heating and cooling loads and the ratio of heating-to-cooling load are presented in Figures 2-6. The maps show that much of the South has cooling loads that are comparable to heating loads. Keep in mind that these loads are the building loads, and do not include equipment efficiencies. The costs described later in Section 4.3 do include efficiencies and local fuel costs.

A) though the northern area of the SSEC region has a significant heating load, there is still a rather significant cooling load. This reinforces the fact that passive solar heating techniques employed in these areas must include consideration of summer performance.

Another observation is that generally lower heating-to-cooling ratios result from better insulation in the energy-conserving and sun-tempered cases. The increased insulation level had relatively more effect on heating loads than on cooling loads. This is primarily due to the fact that double glazing does not significantly reduce summer solar energy gains over single glazing, but does effectively reduce winter heat losses. 
The relative effect of orientation can also be seen in the maps. As discussed earlier, orientation does not significantly affect heating loads, but does affect cooling loads due to the higher solar gains through east-west glazing. Therefore, orienting the house to face south increases the heating to c00ling load ratio due to the decrease in cooling load.

\subsection{Effect of Increased Insulation, House Orientation, and Sun Tempering}

To help illustrate the trends, more maps were generated. Figure 7 shows the annual energy load savings resulting from the higher insulation level of the energy-conserving house. Since the same insulation levels were used throughout the region, the savings increase as one moves north. Thus, in general, the insulation is - as expected - more cost effective as one moves north. However, even the warmest climates have significant savings from the increased insulation.

The effect of changing the house orientation to face south is indicated in Figure 8. In this case, the savings increase as one progresses southward. In fact, the savings are entirely due to the reduction in cooling load resulting from the reduced amounts of east-west facing glass in the south-facing house. For these calculations, the cooling loads for the north-south axis case were computed for average shading, while the east-west axis cooling loads were computed for awning shading. The rationale is that the south-facing windows in the east-west axis case can easily be shaded by roof overhangs.

The additional savings resulting solely from relocating the glazing in the energy-conserving, east-west axis case (sun-tempering) are shown in Figure 9. Although the savings are nominal in the deep South, there is essentially no cost to achieve these savings. The larger savings in the colder regions result primarily from the increased solar aperture and heating load reduction.

The cooling load impact of window orientation is highly dependent on the shading devices that are assumed. This study generally takes a middle stance and uses window cooling loads averaged between no shading and awning shading. Cooling load reductions achieved by reorienting the house to face south would be much higher if less shading were employed. 


\subsection{Heating and Cooling Cost Ratios}

Typical fuel costs and efficiencies were considered as discussed in Section 3.3. The cost of heating and cooling and the ratio of heating costs to cooling costs are presented in Table 3 for the sun-tempered house.

It is obvious that the choice of heating system can have a large impact on the relative costs of heating and cooling and, consequently, on the design emphasis of the building. Electric resistance heat has the greatest impact on the cost and cost ratio, resulting in heating costs that dominate throughout most of the region. Natural gas heating-to-cooling cost ratios are much closer to the heat pump heating-to-cooling cost ratios.

One implication of different fuel costs for the designer is illustrated by examining the ratios for Jackson, Mississippi. For electric resistance heating, a house with sun-tempering would have a heating bill 1.62 times the cooling bill. Thus, the designer would tend to apply techniques that favor heating load reduction. On the other hand, for a heat pump or natural gas, the heating bill would be 0.81 and 0.44 times the cooling bill, respectively. In this case, the designer would emphasize techniques that favor cooling load reduction. of course, when the ratio is near one, the designer must consider both the heating and cooling impact of any conservation alternative. In many locations, however, the cost ratios for all three heating systems are greater than one, indicating that the designer should favor techniques that reduce the heat load in those cities and pay attention to the cooling load impact as well.

Another implication of different fuels and costs is the variety in cost savings resulting from energy conservation and passive solar. For example, a sunspace that saves 30 percent of the heating load would have significantly different energy cost savings depending on fuel and equipment type. It is not unusual for certain conservation options to be economically viable for one fuel type and not another. 


\subsection{SUMMARY}

Using conventional building community calculation methods, this report has illustrated typical residential heating and cooling loads for the South, and the effects of varying insulation level, orientation, sun-tempering, heating system type, and fuel cost.

The following observations summarize the results:

- Most of SSEC's region has both heating and cooling loads that are significant.

- From a heating standpoint, east-west glazing is approximately 50 percent as effective as south glazing.

- Increased insulation can greatly reduce space conditioning loads throughout the region.

- Double glazing produces more relative reduction of heating load than cooling load.

- Orienting the house to face south greatly reduces cooling loads, with little effect on heating loads.

- Relocation of glazing in a south-facing house results in "free" energy savings, which increase wi th cooler climates.

- Fuel type and HVAC equipment efficiency can greatly impact the cost of heating and cooling and, hence, the building design.

Future efforts will be directed at assessing the combined heating and cooling effects of common passive building techniques.

\section{$\underline{6.0 \quad \text { REFERENCES̈ }}$}

(1) Los Alamos Scientific Laboratory, Passive Solar Design Handbook, Volume Two of Two Volumes: Passive Solar Design Analysis, National Technical Information Service, DOE/CS-0127/2, January 1980.

(2) Mazria, Edward, The Passive Solar Energy Book, Rodale Press, Emmaus, Pennsylvania, 1979. 
(3) ASHRAE Handbook and Product Directory, 1977 Fundamentals, American Society of Heating, Refrigerating, and Air-Conditioning Engineers, Inc., New York, New York, 1977.

(4) Insulation Manual - Homes, Apartments, NAHB Research Foundation, Inc., Rockville, Maryland, 1979.

(5) Sullivan, Paul W., et. al., "Incremental Cooling Load Determination for Passive Direct Gain Heating Systems," Lawrence Berkeley Laboratory, LBL-12048, May 1981 .

(6) BLAST: Building Loads Analysis and System Thermodynamics, Construction Engineering Research Laboratory, U.S. Department of the Army, Champaign, Illinois, 1977.

(7) Weir, Sue B., Residential Utility Rate Guide for SOLCOST Data Bank Cities, Johnson Environmental and Energy Center, The University of Alabama in Huntsville, March 1981. 


\section{TABLE 1}

INSOLATION TRANSMISSION RATIO:

East-West Double Glazing vs. South Double Glazing

\begin{tabular}{|c|c|c|c|c|}
\hline \multirow[t]{2}{*}{ Month } & \multicolumn{4}{|c|}{$\begin{array}{r}\text { Ratio of insolation transmitted through East/West } \\
\text { to South double glazing } \\
\end{array}$} \\
\hline & \multicolumn{2}{|c|}{$\begin{array}{l}\text { Reference } 1^{*} \\
34^{\circ} \mathrm{N} \\
390^{\circ} \mathrm{N}\end{array}$} & \multicolumn{2}{|c|}{$\begin{array}{l}\text { Reference 2**} \\
320 \mathrm{~N}\end{array}$} \\
\hline October & 0.70 & 0.58 & 0.55 & 0.45 \\
\hline November & 0.52 & 0.44 & 0.38 & 0.32 \\
\hline December & 0.46 & 0.41 & 0.34 & 0.27 \\
\hline January & 0.48 & 0.42 & 0.38 & 0.31 \\
\hline February & 0.59 & 0.50 . & 0.54 & 0.44 \\
\hline March & 0.86 & 0.72 & 0.85 & 0.69 \\
\hline April & 1.24 & 1.06 & 1.53 & 1.20 \\
\hline $\begin{array}{l}\text { Degree-day } \star \star \star \\
\text { Weighted Average }\end{array}$ & 0.58 & 0.52 & 0.50 & 0.44 \\
\hline
\end{tabular}

* Values are based on monthly averages.

** Values are based on clear-day solar heat gains for the 21 st of the month.

$\star \star \star$ For $39^{\circ} \mathrm{N}$ and $40^{\circ} \mathrm{N}$, degree-days for Washington, DC were used, for $32^{\circ} \mathrm{N}$ and $34^{\circ} \mathrm{N}$, degree-days for Atlanta, GA were used. 
TABLE 2

FUEL COSTS*

\begin{tabular}{|c|c|c|c|}
\hline City & $\begin{array}{c}\text { Elec } \\
\text { Winter } \\
\text { ( } \$ / M N\end{array}$ & $\begin{array}{l}\text { ic } \\
\text { Summer } \\
\text { (u) }\end{array}$ & $\begin{array}{c}\text { Natural } \\
\text { Gas } \\
\text { (\$/MMBtu) }\end{array}$ \\
\hline $\begin{array}{l}\text { Asheville, NC } \\
\text { Atlanta, GA } \\
\text { Baltimore, MD } \\
\text { Birmingham, AL } \\
\text { Charleston, SC } \\
\text { Charleston, WV } \\
\text { Dallas, TX } \\
\text { Washington, DC } \\
\text { El Paso, TX } \\
\text { Houston, TX } \\
\text { Jackson, MS } \\
\text { Jacksonville, FL } \\
\text { Little Rock, AR } \\
\text { Louisville, KY } \\
\text { Memphis, TN } \\
\text { Miami, FL } \\
\text { Mobile, AL } \\
\text { Nashville, TN } \\
\text { New Orleans, LA } \\
\text { Norfolk, VA } \\
\text { Oklahoma City, OK } \\
\text { Raleigh, NC } \\
\text { Shreveport, LA } \\
\text { Wilmington, DE } \\
\text { Albuquerque, NM } \\
\text { Boston, MA } \\
\text { Denver, CO } \\
\text { Madison, WI } \\
\text { Portland, OR } \\
\text { Santa Maria, CA }\end{array}$ & $\begin{array}{l}13.88 \\
12.86 \\
17.24 \\
17.73 \\
15.24 \\
13.18 \\
17.13 \\
14.10 \\
19.82 \\
13.59 \\
19.04 \\
26.60 \\
17.87 \\
12.56 \\
11.50 \\
15.62 \\
17.73 \\
10.74 \\
17.54 \\
19.85 \\
16.93 \\
13.89 \\
12.96 \\
23.32 \\
21.80 \\
28.88 \\
17.58 \\
13.86 \\
10.58 \\
12.39\end{array}$ & $\begin{array}{l}13.04 \\
13.60 \\
18.81 \\
15.38 \\
15.35 \\
12.70 \\
20.62 \\
15.30 \\
20.02 \\
18.16 \\
16.69 \\
20.33 \\
14.18 \\
12.48 \\
9.86 \\
11.98 \\
15.38 \\
10.40 \\
16.79 \\
20.84 \\
13.16 \\
13.04 \\
19.05 \\
24.43 \\
21.96 \\
30.43 \\
15.42 \\
16.82 \\
11.02 \\
19.22\end{array}$ & $\begin{array}{l}5.09 \\
3.46 \\
4.61 \\
4.50 \\
3.94 \\
3.94 \\
3.47 \\
4.50 \\
3.28 \\
4.30 \\
3.64 \\
4.96 \\
2.89 \\
3.23 \\
3.03 \\
5.04 \\
3.43 \\
3.10 \\
4.08 \\
4.80 \\
2.92 \\
5.09 \\
3.23 \\
4.52 \\
3.92 \\
5.70 \\
3.71 \\
4.41 \\
5.37 \\
3.51\end{array}$ \\
\hline
\end{tabular}

*Based on monthly consumption of $1000 \mathrm{kWh}$ for electricity and 5000 cubic feet for

natural gas (Reference 7) 
TABLE 3

ANNUAL COST RATIO*

FOR SUN-TEMPERED CASE

\begin{tabular}{|c|c|c|c|c|c|c|}
\hline City & \multicolumn{2}{|c|}{$\begin{array}{c}\text { Resistance } \\
\text { Heating } \\
\end{array}$} & \multicolumn{2}{|c|}{$\begin{array}{l}\text { Heat } \\
\text { Pump }\end{array}$} & \multicolumn{2}{|c|}{$\begin{array}{c}\text { Natural Gas } \\
\text { Heating }\end{array}$} \\
\hline $\begin{array}{l}\text { Asheville, NC } \\
\text { Atlanta, GA } \\
\text { Baltimore, MD } \\
\text { Birmingham, AL } \\
\text { Charleston, SC } \\
\text { Charleston, WV } \\
\text { Dallas, TX } \\
\text { Washington, DC } \\
\text { El Paso, TX } \\
\text { Houston, TX } \\
\text { Jackson, MS } \\
\text { Jacksonville, FL } \\
\text { Little Rock, AR } \\
\text { Louisville, KY } \\
\text { Memphis, TN } \\
\text { Miami, FL } \\
\text { Mobile, AL } \\
\text { Nashville, TN } \\
\text { New Orleans, LA } \\
\text { Norfolk, VA } \\
\text { Oklahoma City, OK } \\
\text { Raleigh, NC } \\
\text { Shreveport, LA } \\
\text { Wilmington, DE } \\
\text { Madison, WI } \\
\text { Albuquerque, NM } \\
\text { Santa Maria, CA } \\
\text { Boston, MA } \\
\text { Portland, OR } \\
\text { Denver, Co }\end{array}$ & $\begin{array}{l}509 / 83 \\
325 / 120 \\
778 / 129 \\
406 / 168 \\
247 / 177 \\
623 / 84 \\
305 / 300 \\
692 / 109 \\
406 / 217 \\
141 / 282 \\
327 / 202 \\
250 / 311 \\
504 / 161 \\
564 / 102 \\
313 / 106 \\
1 / 275 \\
200 / 204 \\
355 / 90 \\
158 / 258 \\
578 / 165 \\
530 / 130 \\
410 / 110 \\
205 / 237 \\
1119 / 140 \\
1783 / 91 \\
1031 / 210 \\
316 / 20 \\
809 / 67 \\
443 / 21 \\
663 / 85\end{array}$ & $\begin{array}{l}=6.13 \\
=2.71 \\
=6.03 \\
=2.42 \\
=1.40 \\
=7.42 \\
=1.02 \\
=6.35 \\
=1.86 \\
=0.50 \\
=1.62 \\
=0.80 \\
=3.13 \\
=5.53 \\
=2.95 \\
=0.00 \\
=0.98 \\
=3.94 \\
=0.61 \\
=3.50 \\
=4.08 \\
=3.73 \\
=0.86 \\
=7.99 \\
=19.59 \\
=4.91 \\
=15.80 \\
=12.07 \\
=21.10 \\
=7.80\end{array}$ & $\begin{array}{l}255 / 83 \\
163 / 120 \\
389 / 129 \\
203 / 168 \\
123 / 177 \\
312 / 84 \\
152 / 300 \\
346 / 109 \\
203 / 217 \\
70 / 282 \\
164 / 202 \\
125 / 311 \\
252 / 161 \\
282 / 102 \\
156 / 106 \\
1 / 275 \\
100 / 204 \\
178 / 90 \\
79 / 258 \\
289 / 165 \\
265 / 130 \\
205 / 110 \\
102 / 237 \\
560 / 140 \\
892 / 91 \\
516 / 210 \\
158 / 20 \\
405 / 67 \\
222 / 21 \\
331 / 85\end{array}$ & $\begin{array}{l}=3.07 \\
=1.36 \\
=3.02 \\
=1.21 \\
=0.69 \\
=3.71 \\
=0.51 \\
=3.17 \\
=0.94 \\
=0.25 \\
=0.81 \\
=0.40 \\
=1.57 \\
=2.76 \\
=1.47 \\
=0.00 \\
=0.49 \\
=1.98 \\
=0.31 \\
=1.75 \\
=2.04 \\
=1.86 \\
=0.43 \\
=4.00 \\
=9.80 \\
=2.46 \\
=7.90 \\
=6.04 \\
=10.57 \\
=3.89\end{array}$ & $\begin{array}{l}267 / 83 \\
125 / 120 \\
297 / 129 \\
147 / 168 \\
91 / 177 \\
266 / 84 \\
316 / 300 \\
316 / 109 \\
96 / 217 \\
64 / 282 \\
89 / 202 \\
67 / 311 \\
116 / 161 \\
207 / 102 \\
118 / 106 \\
1 / 275 \\
55 / 204 \\
147 / 90 \\
52 / 258 \\
200 / 165 \\
131 / 130 \\
215 / 110 \\
73 / 237 \\
310 / 140 \\
458 / 91 \\
291 / 210 \\
95 / 20 \\
368 / 67 \\
321 / 21 \\
268 / 85\end{array}$ & $\begin{array}{l}=3.22 \\
=1.04 \\
=2.30 \\
=0.88 \\
=0.51 \\
=3.17 \\
=1.05 \\
=2.90 \\
=0.44 \\
=0.23 \\
=0.44 \\
=0.22 \\
=0.72 \\
=2.03 \\
=1.11 \\
=0.00 \\
=0.27 \\
=1.63 \\
=0.20 \\
=1.21 \\
=1.00 \\
=1.95 \\
=0.31 \\
=2.21 \\
=5.03 \\
=1.39 \\
=4.75 \\
=5.49 \\
=15.29 \\
=3.15\end{array}$ \\
\hline
\end{tabular}

* Heating Costs/Cooling Costs = Cost Ratio 


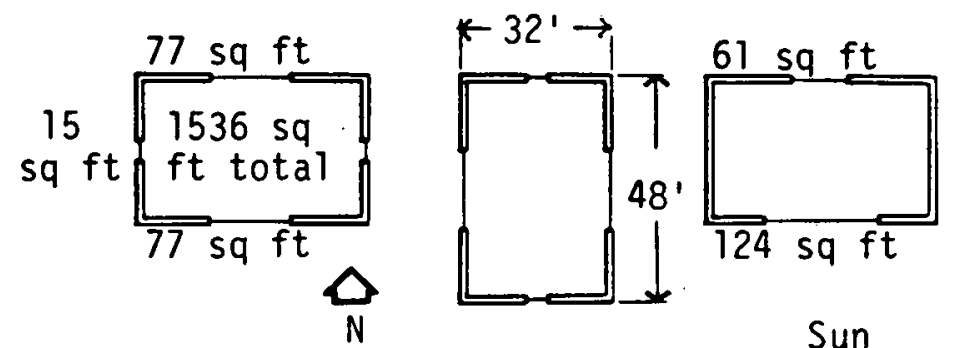

\begin{tabular}{|c|c|c|}
\hline \multirow[b]{2}{*}{ ITEM } & \multicolumn{2}{|c|}{ INSULATION LEVELS } \\
\hline & STANDARD & $\begin{array}{l}\text { ENERGY- } \\
\text { CONSERVING }\end{array}$ \\
\hline $\begin{array}{l}\text { Slab-on-Grade } \\
\text { Perimeter } \\
\text { Insulation }\end{array}$ & None & $R-5$ \\
\hline Ceiling & R- 19 & $R-30$ \\
\hline Walls & $R-11$ & $\begin{array}{l}\mathrm{R}-11 \text { plus } \mathrm{R}-6 \\
\text { sheathing }\end{array}$ \\
\hline Doors & $\begin{array}{l}1 \frac{1}{2} " 1 \\
\text { solid wood }\end{array}$ & $\begin{array}{l}1 \frac{1}{2} " \text { solid } \\
\text { wood with } \\
\text { storm door }\end{array}$ \\
\hline Glazing & Single & Double \\
\hline Infiltration & $\begin{array}{l}1.5 \mathrm{ACH} \\
\text { (Winter) } \\
0.5 \mathrm{ACH} \\
\text { (Summer) }\end{array}$ & $\begin{array}{l}1.0 \mathrm{ACH} \\
\text { (Winter) } \\
0.35 \mathrm{ACH} \\
\text { (Summer) }\end{array}$ \\
\hline Internal Gains & \multicolumn{2}{|c|}{$\begin{array}{l}80,000 \text { Btu/day sensible } \\
\text { (Summer \& Winter) }\end{array}$} \\
\hline & \multicolumn{2}{|c|}{$\begin{array}{l}20,000 \text { Btu/day latent } \\
\text { (Summer) }\end{array}$} \\
\hline
\end{tabular}

Figure 1: BUILDING DESCRIPTIONS 


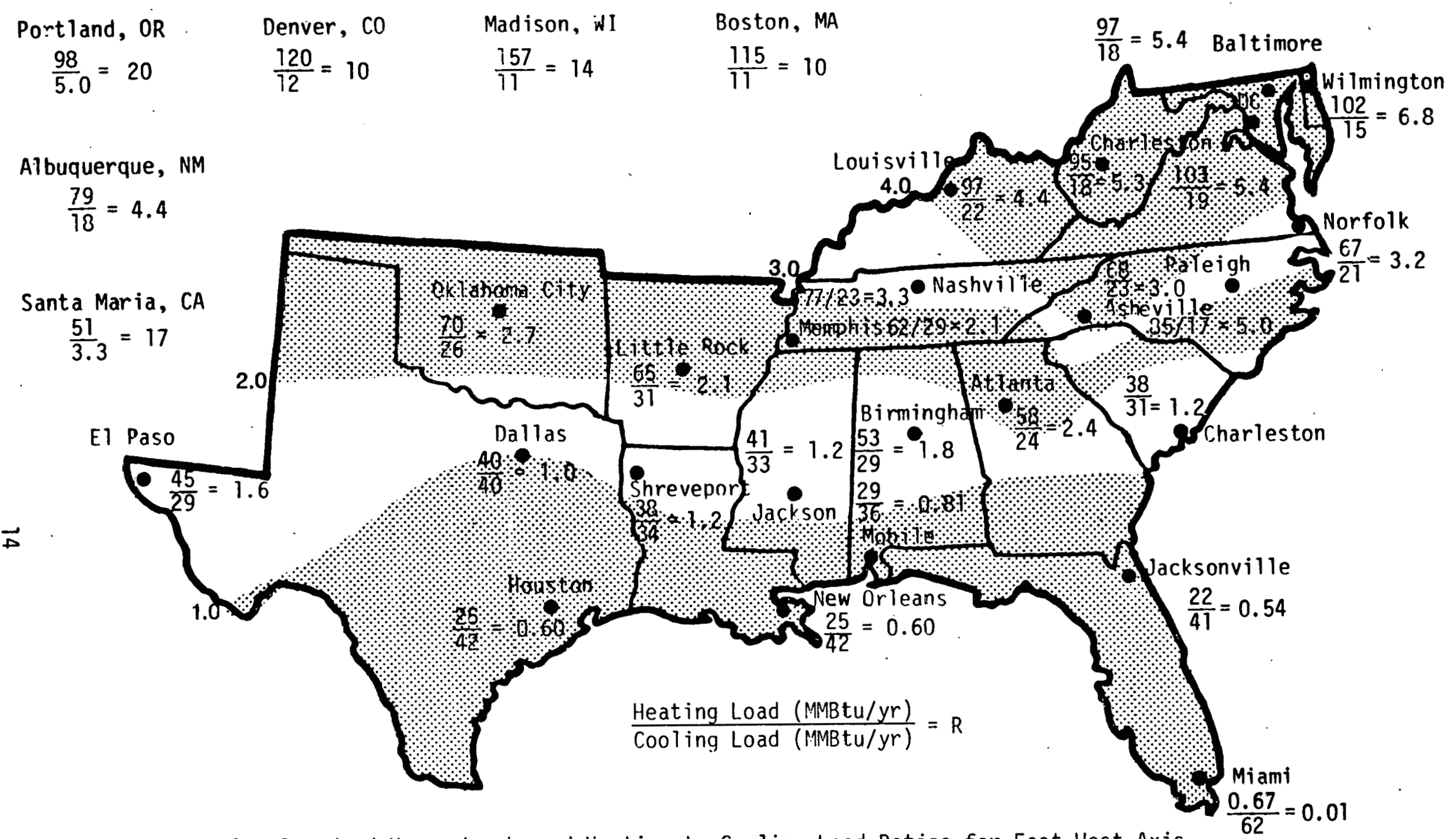

Figure 2 - Standard House Loads and Heating-to-Cooling Load Ratios for East-West Axis 


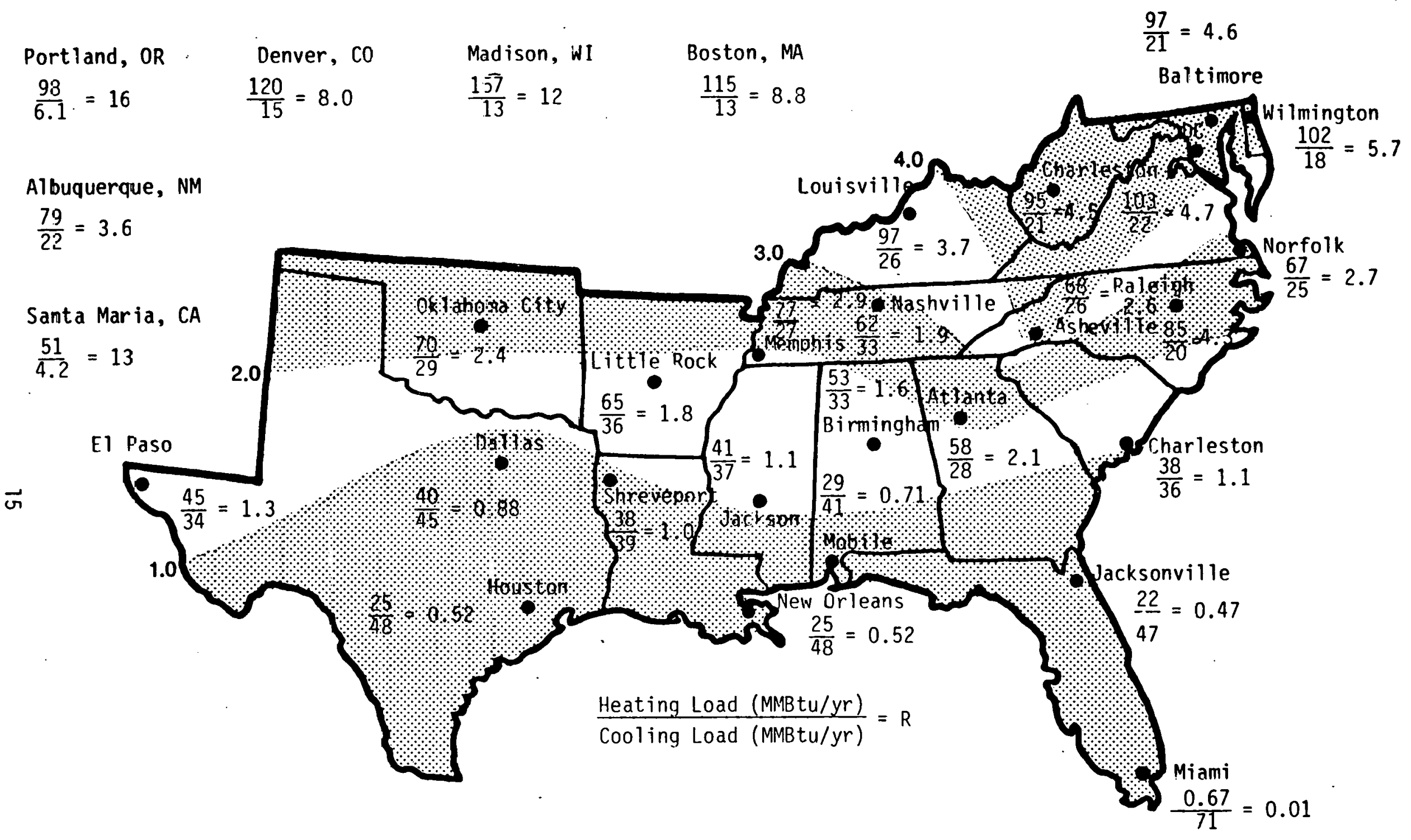

Figure 3 - Standard House Loads and Heating-to-Cooling Load Ratios for North-South Axis 


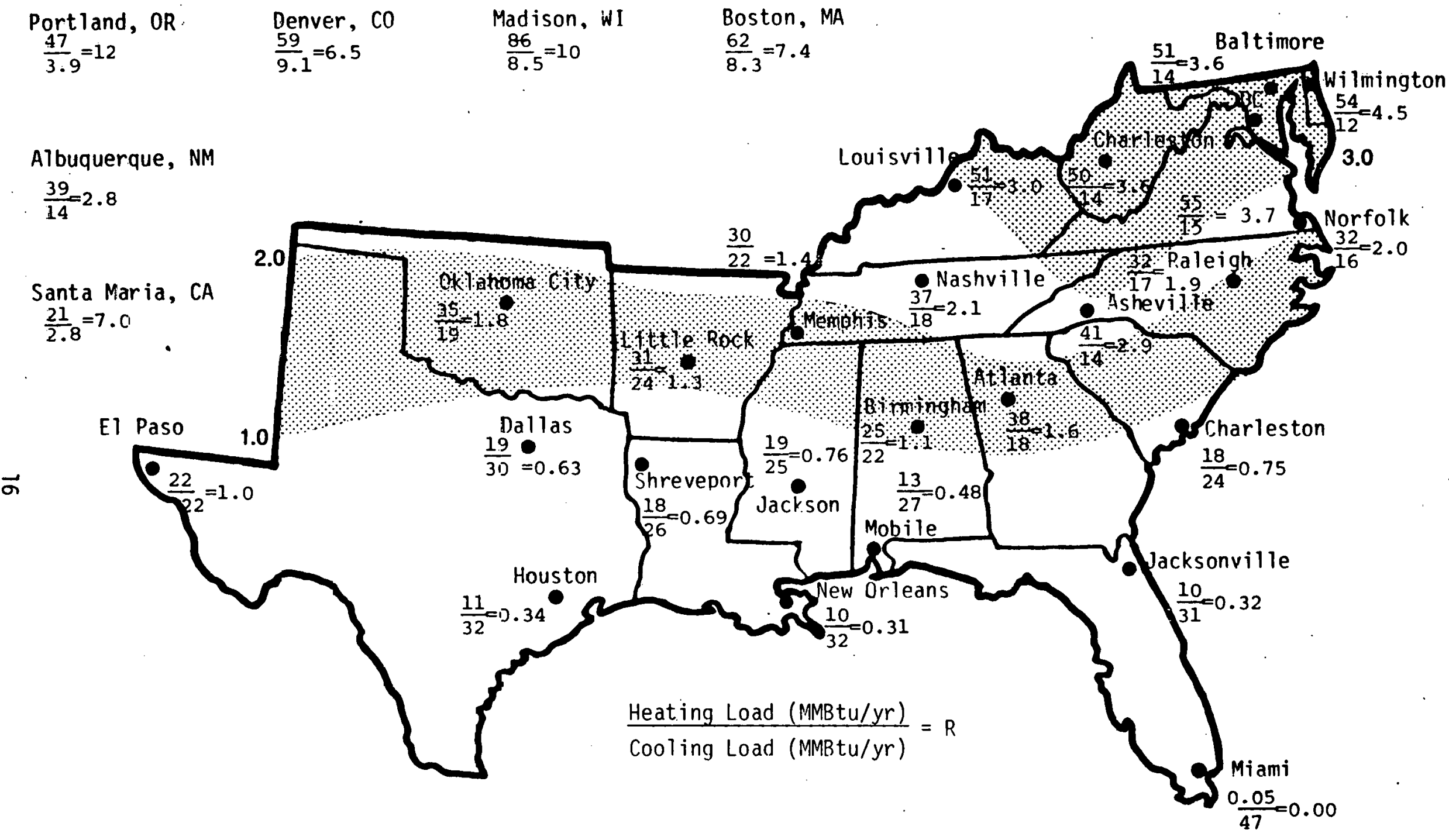

Figure 4 - Energy-Conserving House Loads and Heating-to-Cooling Load Ratios for East-West Axis 


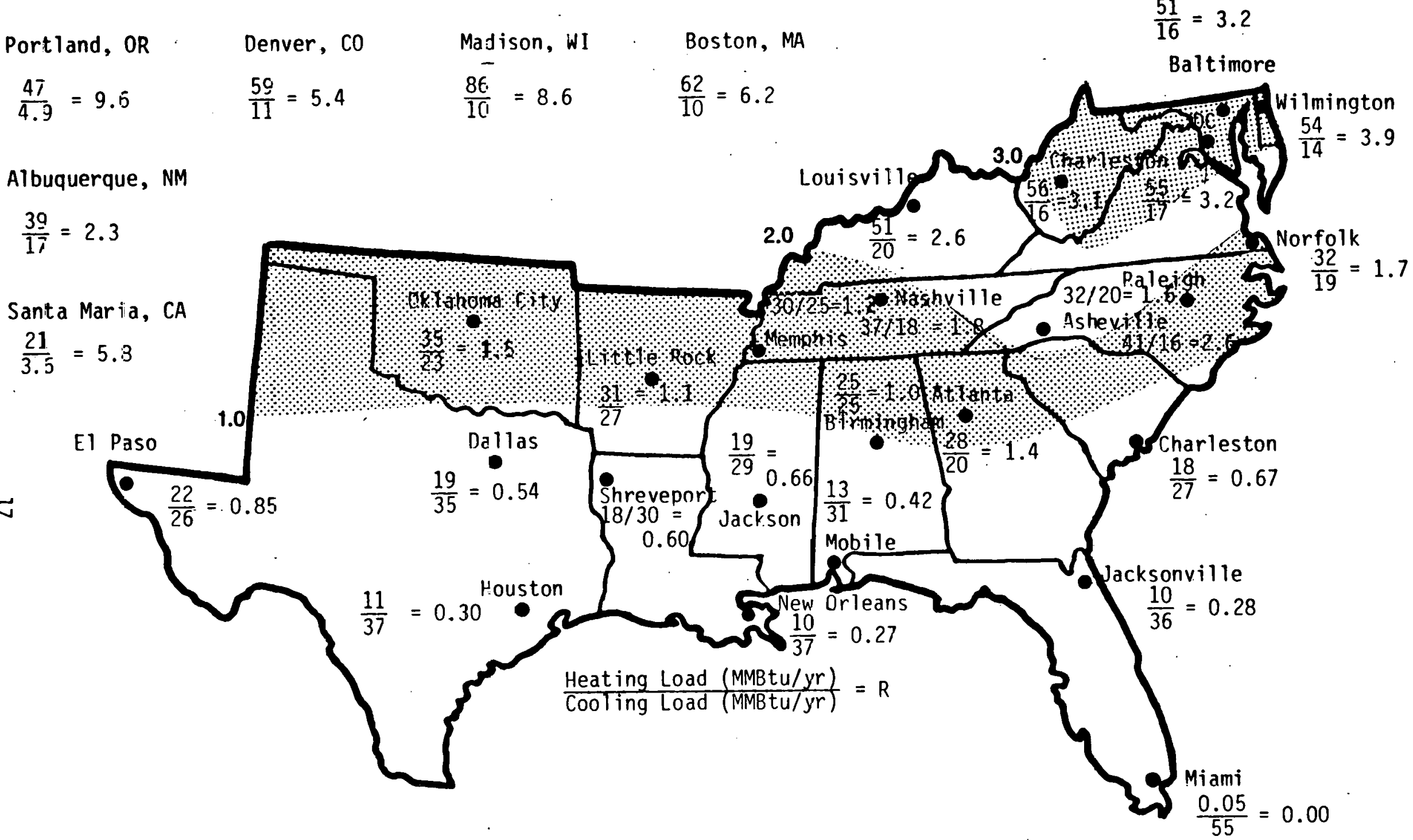

Figure 5 - Energy-Conserving House Loads and Heating-to-Cooling Load Ratios for North-South Axis 


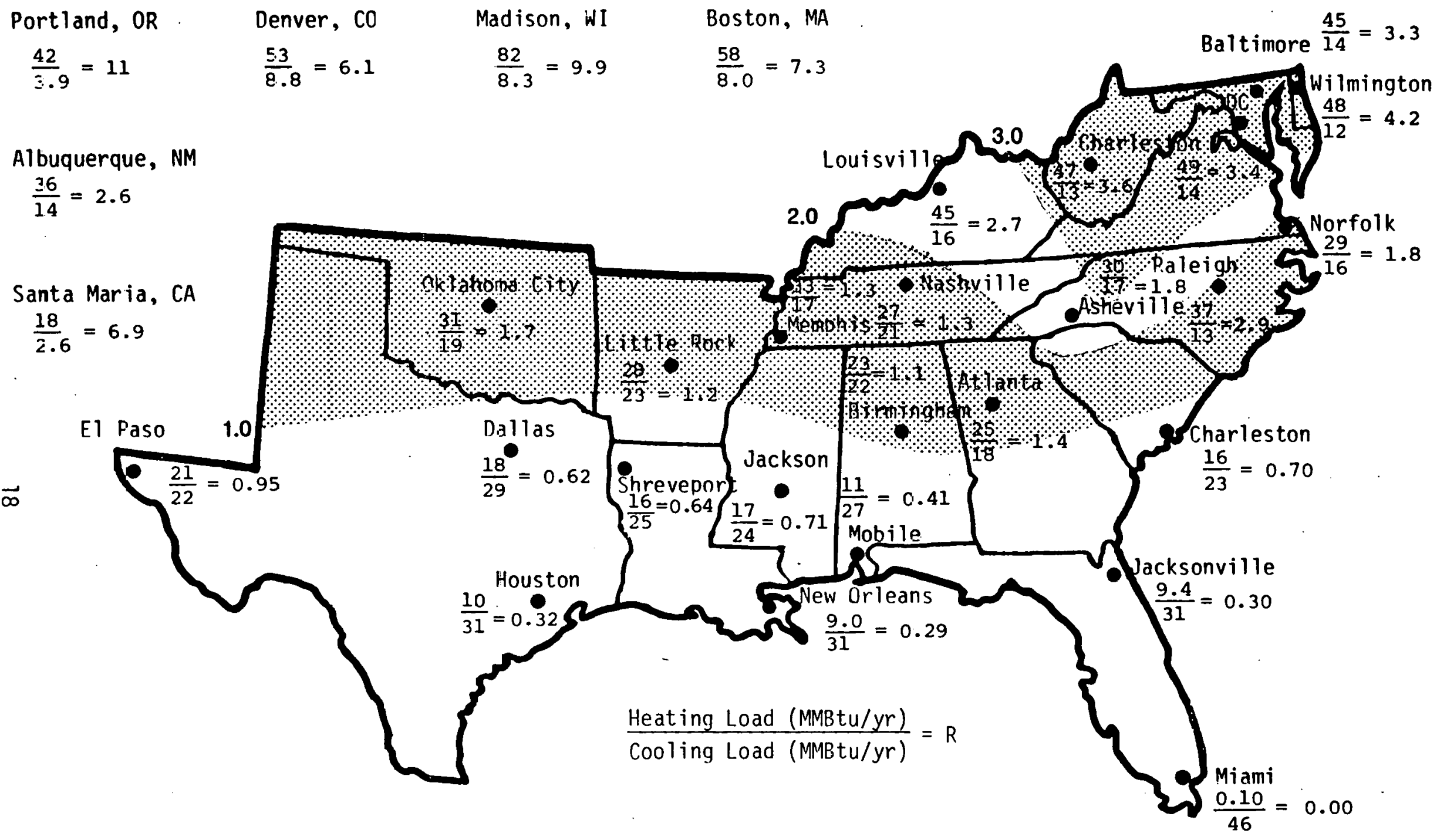

Figure 6 - Sun-Tempered House Loads and Heating-to-Cooling Load Ratios 
Portland, OR

52

Denver, $C O$

65

Madison, WI

74
Boston, MA

56
51

Baltimore

Albuquerque, NM

44

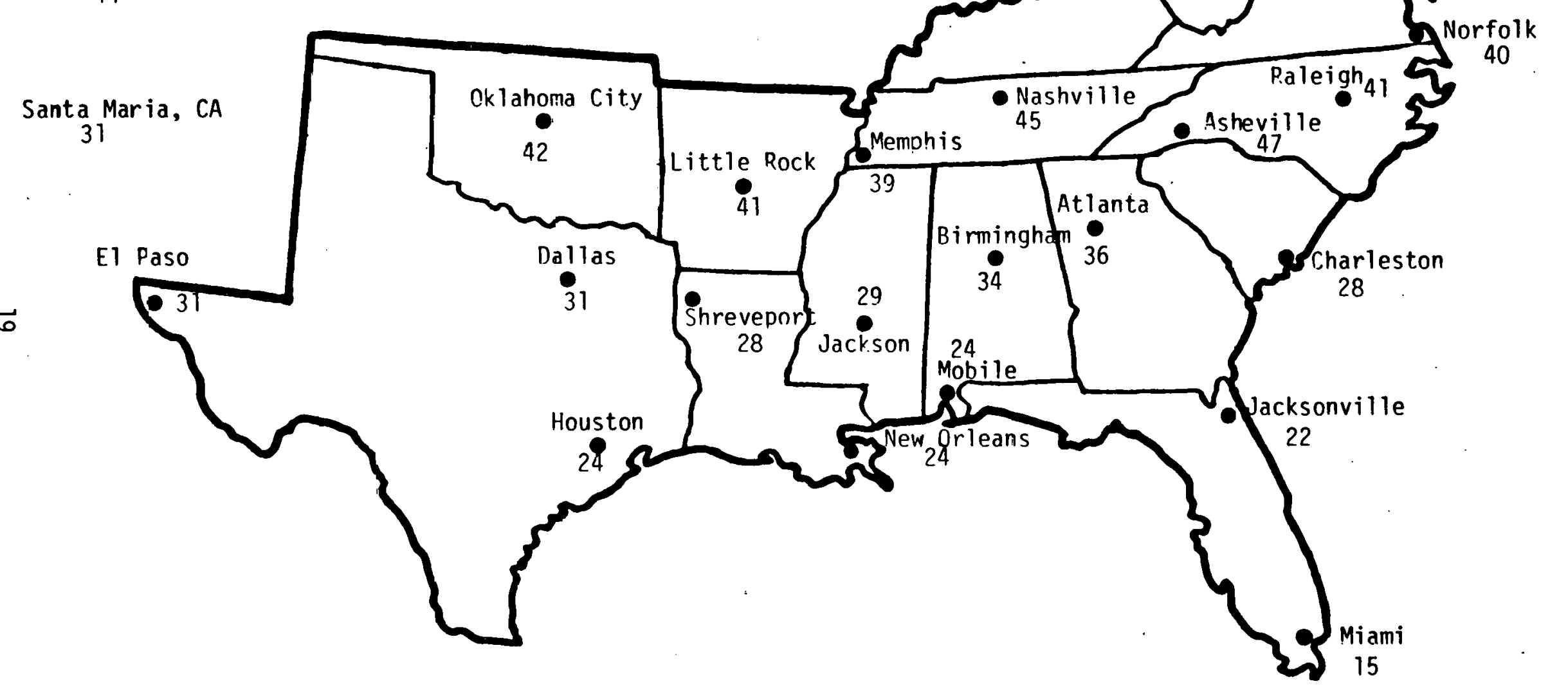

Figure 7 - Annual Energy Savings of Energy-Conserving House Over Standard House (MMBtu/yr) 


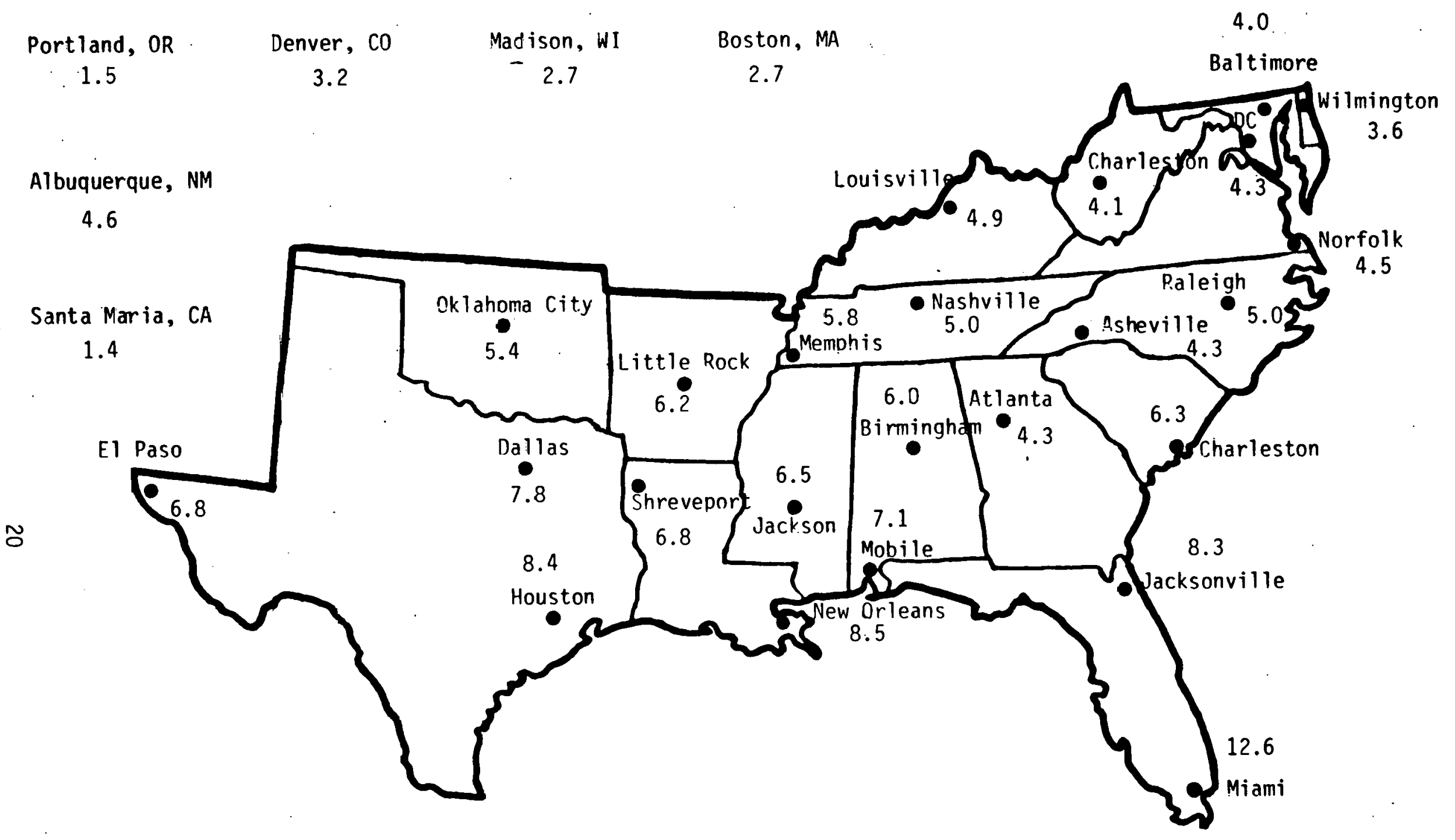

Figure 8 - Annual Energy Savings From Changing Energy-Conserving House Orientation To Face South (MMBtu/yr) 
Portland, OR

5

Denver, Co

7
Madison, WI

5
Boston, MA

4

Albuquerque, NM

3

Santa Maria, CA

$\simeq$

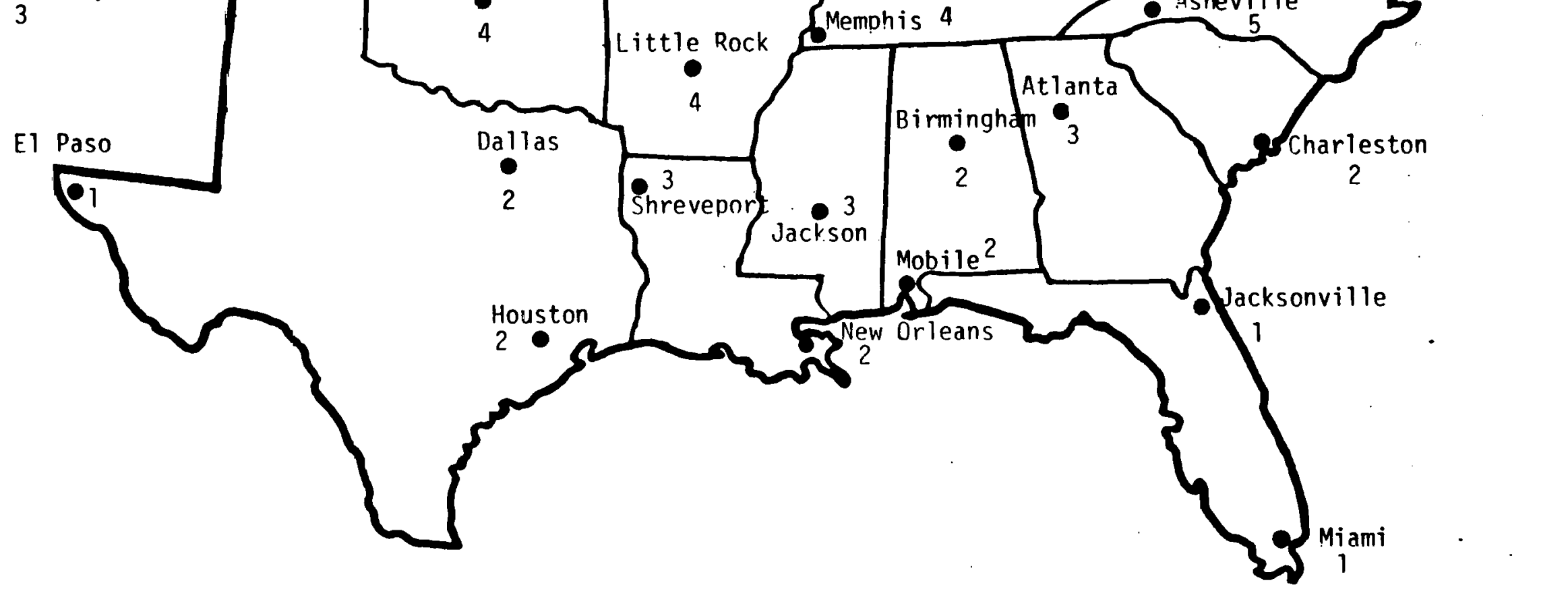

Figure 9 - Annual Energy Savings from Relocating Glazing to South Side (MMBtu/yr) 